Mladen Jovičić

Archaeological Institute Belgrade

mladen_jovicic@yahoo.com

Saša Redžić

Archaeological Institute Belgrade

sasa.redzic@gmail.com
UDK: 904:728.8"652"(497.11);

902.2:728(497.11)"198"

ID: 196127756

Original research article

Received: July 08, 2011

Accepted: September 05, 2011

\title{
LATE ROMAN VILLA ON THE SITE LIVADE KOD ĆUPRIJE - A CONTRIBUTION TO THE STUDY OF VILLAE RUSTICAE IN THE VICINITY OF VIMINACIUM
}

\begin{abstract}
The Late Roman villa rustica at site Livade kod ćuprije, located $650 \mathrm{~m}$ south of Viminacium was explored in 1983. Although this site had been explored nearly 30 years ago, the remains of the villa have not been known in the scientific community until today. The remains of a rectangular object with an open vestibule in the middle section were found on this site. This object was made of stone, brick and mortar, while the only decoration found in traces was marble wall paneling. Several artifacts characteristic for the daily life of residents in villas, besides a few tools that indicate economic activities, were found together inside the object. The villa is dated to the middle and second half of the $4^{\text {th }}$ century, like as the villas discovered at sites Burdelj, Na Kamenju, Rudine and Stig, all in the vicinity of Viminacium.
\end{abstract}

\section{KEY WORDS: MOESIA PRIMA, VIMINACIUM, VILLA RUSTICA, $4^{\mathrm{TH}}$ CENTURY, SOUTH NECROPOLISES.}

\section{INTRODUCTION}

Although very important to the study of the economy of a city, little attention was paid to villae risticae, despite the long history of research of Viminacium. The villa rustica represents a dominant model of landownership and agricultural production typical for the period of Late Republic, as well as during the whole period of Empire. Namely, those villas represent agricultural households with rooms intended for the owner (pars urbana), which are separated from the manufacturing part of the villa (pars rustica). This manufacturing part contains chambers for production, storage, barns, mills, workshops, as well as housing objects for slaves and staff. Slaves and freedmen were the main manufacturing force on these estates and were supervised by a special worker named vilicus.

Researches of villas last over 200 years, during which numerous examples were examined across the territory of the Empire, from the Black Sea to Portugal, and from Yorkshire to the Sahara. ${ }^{1}$ Numerous remains of villas were also found

1 Percival 1981, 51.

* The article results from the project: IRS - Viminacium, Roman city and legionary camp - research of material and non material culture of inhabitants by using modern technologies of remote sensing, geophysics, GIS, digitalisation and 3D visualisation (no 47018), funded by Ministry of Education, Science and Technological Development of the Republic of Serbia. 
in our neighborhood, on the territory of Hungary ${ }^{2}$ and Croatia. ${ }^{3}$ An extensive typology was given by J.T. Smith with a depiction of approximately 1,100 plans of villas throughout the Empire. ${ }^{4}$

When it comes to villas on the territory of present-day Serbia, the first significant study concerning the subject and also the first synthesis was given by Miloje Vasić in 1970. He described previously explored villas in the former Yugoslavia. ${ }^{5}$ From that period until today, a great number of villas have been explored on our territory. Previous studies concerning these villas were mostly focused on the remains of architecture and finds. Recently, this issue has been elaborated and a good review of villas investigated up to this date has been given, with topographic and typological analysis. ${ }^{6}$

Little is known about villas on the territory of Viminacium, especially if the significance of this town during the Antique period is taken into account. A specific problem is the fact that the remains of the so far explored villas are not entirely available to the general scientific community. The remains of villa at the site Livade kod ćuprije are just one example more. The objective of this study is to present the results of research, to determine the possible purpose of the object based on the finds and architecture, as well as to discuss the problem of the distribution of villas in the vicinity of Viminacium and across the territory of Moesia Prima during the $4^{\text {th }}$ century.

2 Tomas 1964; Biró 1974.

3 Begović, Schrunk 2003; Leleković, Rendić-Miočević 2012.

4 Smith 1997.

5 Vasić 1970.

6 Ilić 2012, 74-82, 91-113.

\section{VILLAE RUSTICAE IN THE} VICINITY OF VIMINACIUM

Viminacium, the biggest urban settlement in the province of Upper Moesia was founded in the $1^{\text {st }}$ century A.D. It is located on the right bank of the river Mlava, near the confluence with the Danube, and the contemporary town of Kostolac. After Domitian's division of Moesia to Upper and Lower in the year 86 A.D., Viminacium became the capital of the province of Upper Moesia (Moesia Superior) with a constant military crew of the Seventh Claudian Legion (Legio VII Claudia) commanded by a legate. ${ }^{7}$ During the reign of Hadrian and his visit to Upper Moesia in the year 117 A.D., Viminacium received the status of municipium. In the year 239 A.D., the town gains the status of colonia, during the reign of emperor Gordian III. In this period Viminacium rises politically and economically. After Diocletian's reforms during the $4^{\text {th }}$ and $5^{\text {th }}$ century, Viminacium was the capital of the province of Moesia Prima. ${ }^{8}$

A roman town was not limited only to the settlement, but included a larger area - ager or territorium. In the period when Viminacium was a municipium, its territory included larger part of the plain in the lower course of the Mlava, nowadays called Stig. When it gained the status of colonia, Viminacium spread its land to the whole area of Stig and Veliko Gradište (Pincum) along with the mine. ${ }^{9}$ Stig is the second largest plain in Serbia. Its boundaries are the Danube River on the north, the mount Sopotska greda and the river Mlava on the west and Homolje Mountains on the east and southeast. ${ }^{10}$ Many archeological remains throughout the territory of Stig indicate the existence of properties of independent landowners. ${ }^{11}$ The fertile plain of Stig was favorable to the development of all branches of agriculture, especially grain cultivation.

7 Спасић- Ђурић 2002, 21.

8 Mirković 1986, 21-59.

9 Поповић 1968, 30.

10 Ђокић, Јацановић 1992, 63.

11 Спасић - Ђурић 2002, 44. 


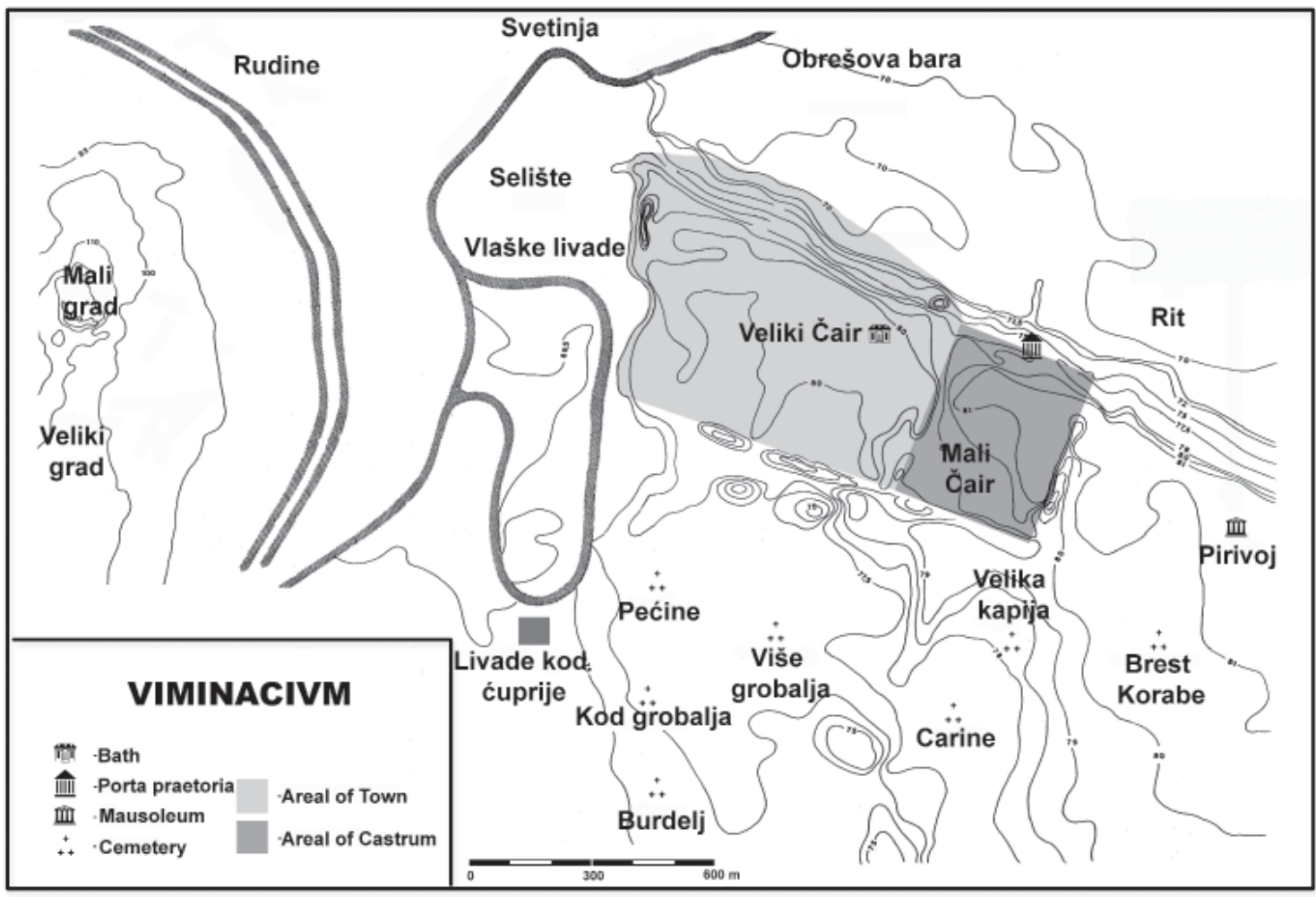

Map 1. Viminacium sites

During the many years of research in Viminacium, the remains of several villas were found. Villas were discovered at sites: Burdelj, ${ }^{12}$ Livade kod ćuprije, ${ }^{13} \mathrm{Na}$ Kamenju, ${ }^{14} \mathrm{Nad}$ Klepečkom, ${ }^{15}$ Rit, ${ }^{16}$ Rudine $^{17}$ and Stig. ${ }^{18}$ The remains of villas from the sites Stig, Rit and Rudine have been described in detail, while villas on the sites Burdelj, Livade kod ćuprije and $\mathrm{Na}$ Kamenju have been just casually mentioned, without a clear description and a proper analysis of found remains. Recently, the first detailed analysis of above mentioned villas has been conducted with topographic and typological determination. ${ }^{19}$

12 Зотовић 1980, 97.

13 Raičković, Redžić 2006, 81-105.

14 Golubović, Korać 2008, 35.

15 The remains of villas on the site Nad Klepečkom were explored in 2010. and 2011., the processing of materials is in progress.

16 Mikić, Stojanović, Mrđić 2006, 21-26.

17 Поповић, Иванишевић 1988, 168-170.

18 Redžić, Raičković, Miletić 2006, 47-56.

19 Jovičić 2011.

\section{LIVADE KOD ĆUPRIJE - VILLA'S POSITION AND RESEARCH HISTORY}

The site Livade kod ćuprije is located in the proximity of the site Pećine, $650 \mathrm{~m}$ southwest of Viminacium, near the river Mlava (Map 1). The site was explored during the construction of thermal power plant Kostolac B, when the ground was being leveled to construct future plants. Rescue excavations were carried out by experts of the Archeological Institute in Belgrade, and the Republic Institute for Cultural Heritage Preservation, under the direction of Ljubica Zotović (Fig. 1). During the research of the sites Pećine and Livade kod ćuprije, excavators found three kilns for burning brick, four kilns for burning pottery, two Early Christian churches, a small number of inhumated graves and the remains of a villa. The remains of the kilns were published in detail, ${ }^{20}$ while the remains of the building which was in-

20 Raičković, Redžić 2006. 


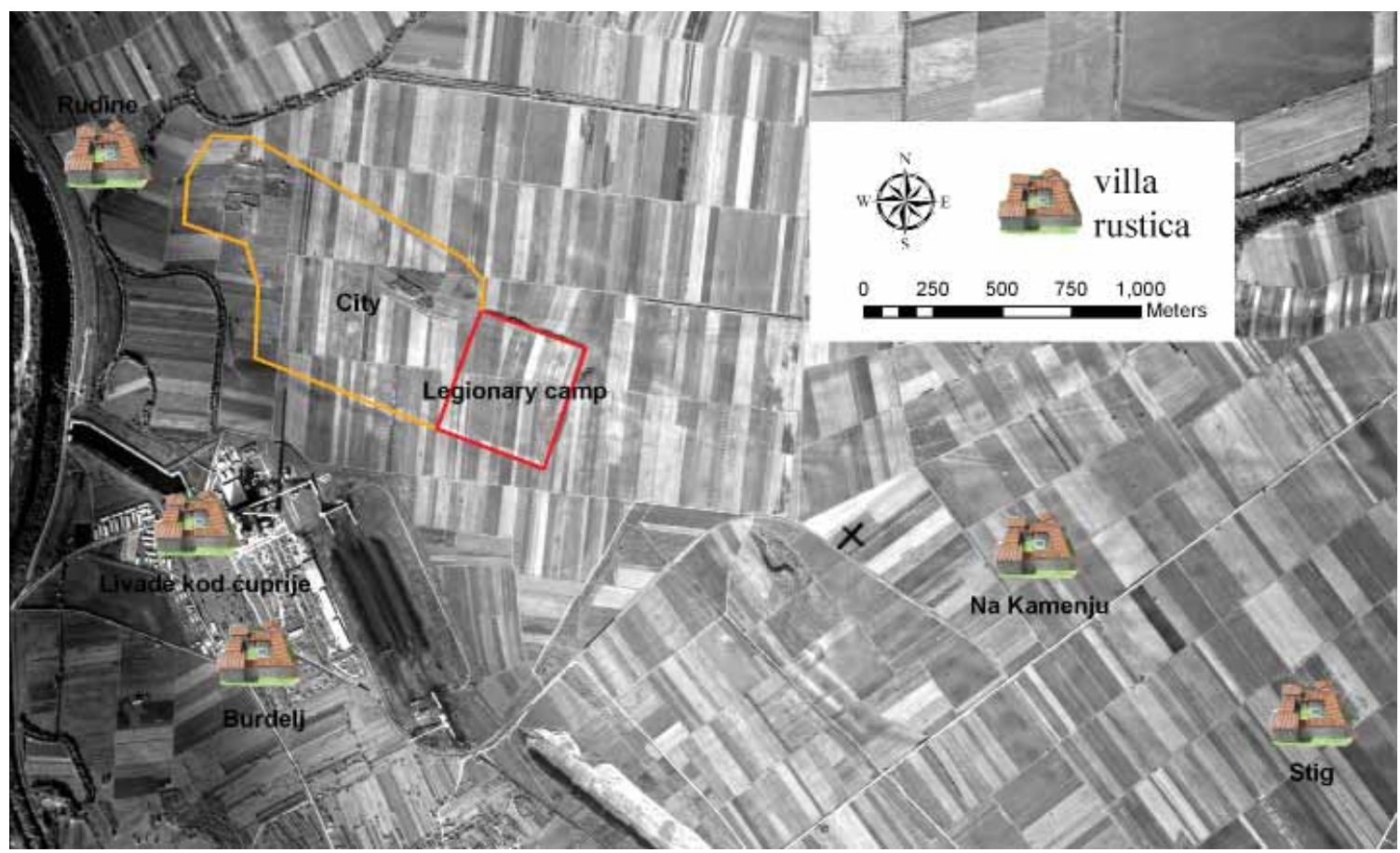

Map 2. Villas from $4^{\text {th }}$ century in the vicinity of Viminacium

terpreted as villa rustica by researchers, were only partially described and until now, were never a part of a separate study. During the rescue excavation in 1983, the Roman villa was discovered. The remains of the object were located on the site of present-day Distribution facility, which is located opposite from the management building of thermal power plant Drmno. The remains of villa were damaged during the field leveling in 1982. Excavations of the villa were carried out in April and May of 1983. The object, as well as the late Antique layer at the area around the object, was built on a layer from an older period. Remains of a pottery kiln were found beneath the object and dated in the $2^{\text {nd }}$ or $3^{\text {rd }}$ century. This kiln belonged to a complex with pottery and brickwork in Viminacium. Until now, 13 pottery and brick kilns that belonged to the complex were found, and they are dated from the late $2^{\text {nd }}$ century to the end of the $3^{\text {rd }}$ century A.D. ${ }^{21}$ Artifacts discovered in the objects that were built above the kilns or that were found in the area between the kilns, as well as in the inhumated graves on this area, are dated to the

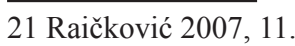

period of the first half of the $4^{\text {th }}$ century A.D. ${ }^{22}$ According to the researchers who carried out the excavation of southern necropolises of Viminacium, a rural settlement was formed on the abandoned necropolis Pećine (formed during the second half of the $1^{\text {st }}$ century) in the $4^{\text {th }}$ century. ${ }^{23}$ The remains of the explored villa certainly affirm this hypothesis.

The exact position of the villa is ascertained circumstantially based on the data from the documentation, because the situation plan is not complete. The remains of villa are not presented on a previously published situation plan of the site Pećine on the area which has been explored southeast from the site Livade kod ćuprije (Fig. 2) ${ }^{24} \mathrm{On}$ that plan, as we can see, the remains of two Early Christian churches A and B are presented and date back to the $4^{\text {th }}$ century A.D., as well as villa.

22 Raičković, Redžić 2006, 88.

23 Зотовић, Јордовић 1990, 2.

24 Raičković, Redžić 2006, 91, P.I. 


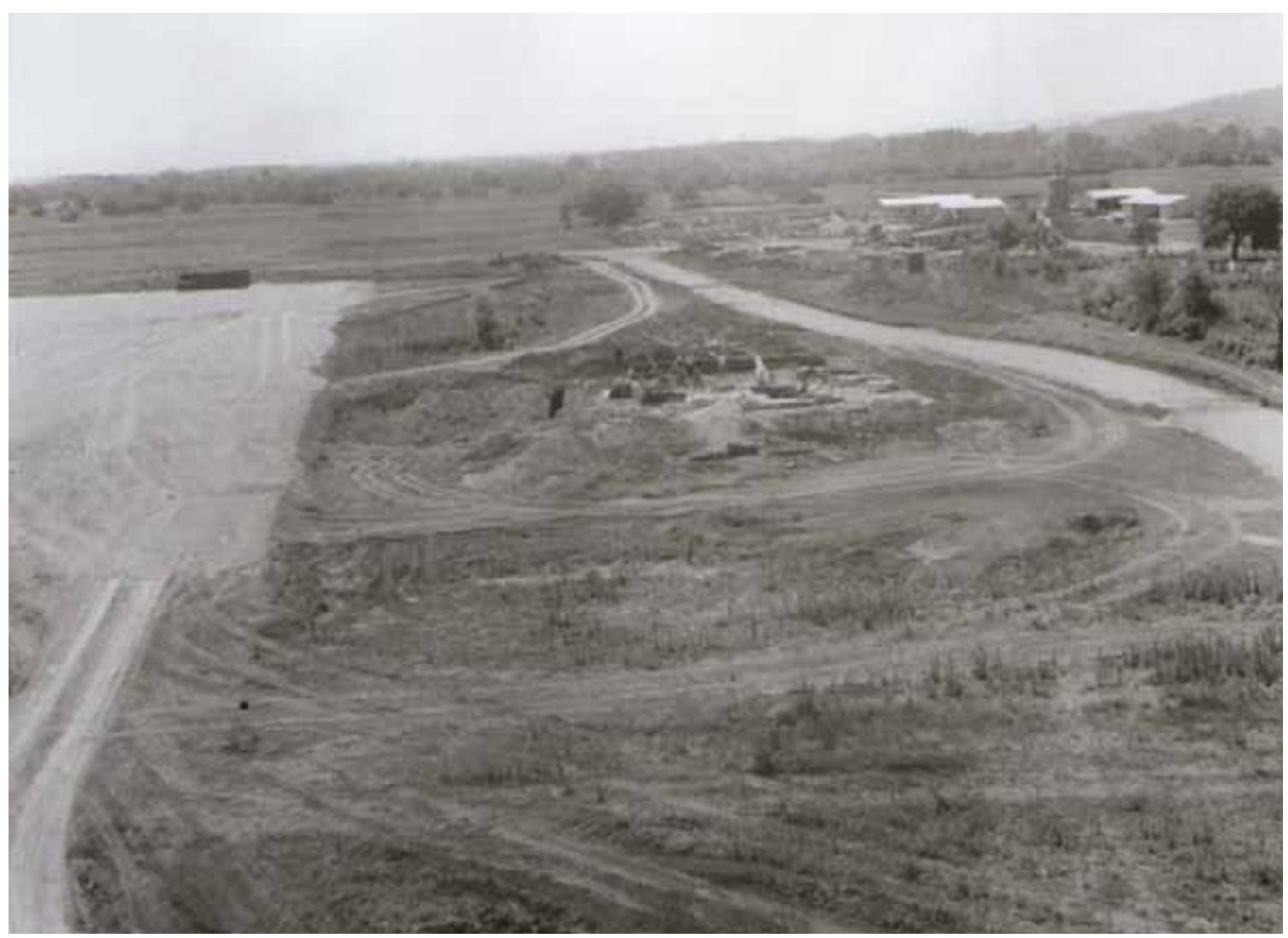

Figure 1. Archaeological excavation during construction of thermal power plant Kostolac B

\section{Villa's architecture}

Villa is rectangular in shape and consists of 8 rooms and a large vestibule in the central part (Fig. 3). Room 1, located in the southwestern part of the villa, has an extension in the form of a semicircular apse. The dimensions of the explored villa are $21 \times 16,30 \mathrm{~m}$. The object with its longer side is faced in the north-south direction, with a deviation of 26 degrees towards west on its northern part.

Foundation footing of the object was built in dry stone wall from crushed bricks and broken schist. Fragments of brick were stacked aslant. The width of the mentioned dry stone wall is 10$12 \mathrm{~cm}$, and the height is $20 \mathrm{~cm}$. The exceptions are wall 2, the eastern wall in rooms 1,5 and 6 , and wall 3 , which is the southern wall in rooms 1, 3 and 4 . The foundation parts of the walls are built in technique opus spicatum (two rows of bricks stacked aslant in herringbone pattern). Surface parts of the walls were built in technique opus mixtum with uniformly stacked fragments of schist stone and brick, which were bound by lime mortar (Fig. 4). ${ }^{25}$ Bigger and more evenly broken fragments of brick and schist were stacked on the front of the wall, while smaller fragments filled the wall. The width of the walls is $0,60 \mathrm{~m}$. Wall 4 , that closes the rooms 2 and 4 on the northern side, is the best preserved wall of the object, and the height of the wall is preserved in the range from 40 to $60 \mathrm{~cm}$.

Room 1 is located in the southwestern part of the villa. With its dimensions $6,40 \times 5,75 \mathrm{~m}$, this room represents the biggest room in the object. Southern side is closed with semicircular apse. The apse, with its radius of $2,80 \mathrm{~m}$, was partially destroyed during the digging of a concrete

25 For a description of these techniques see: Adam 2005, $188,277$. 

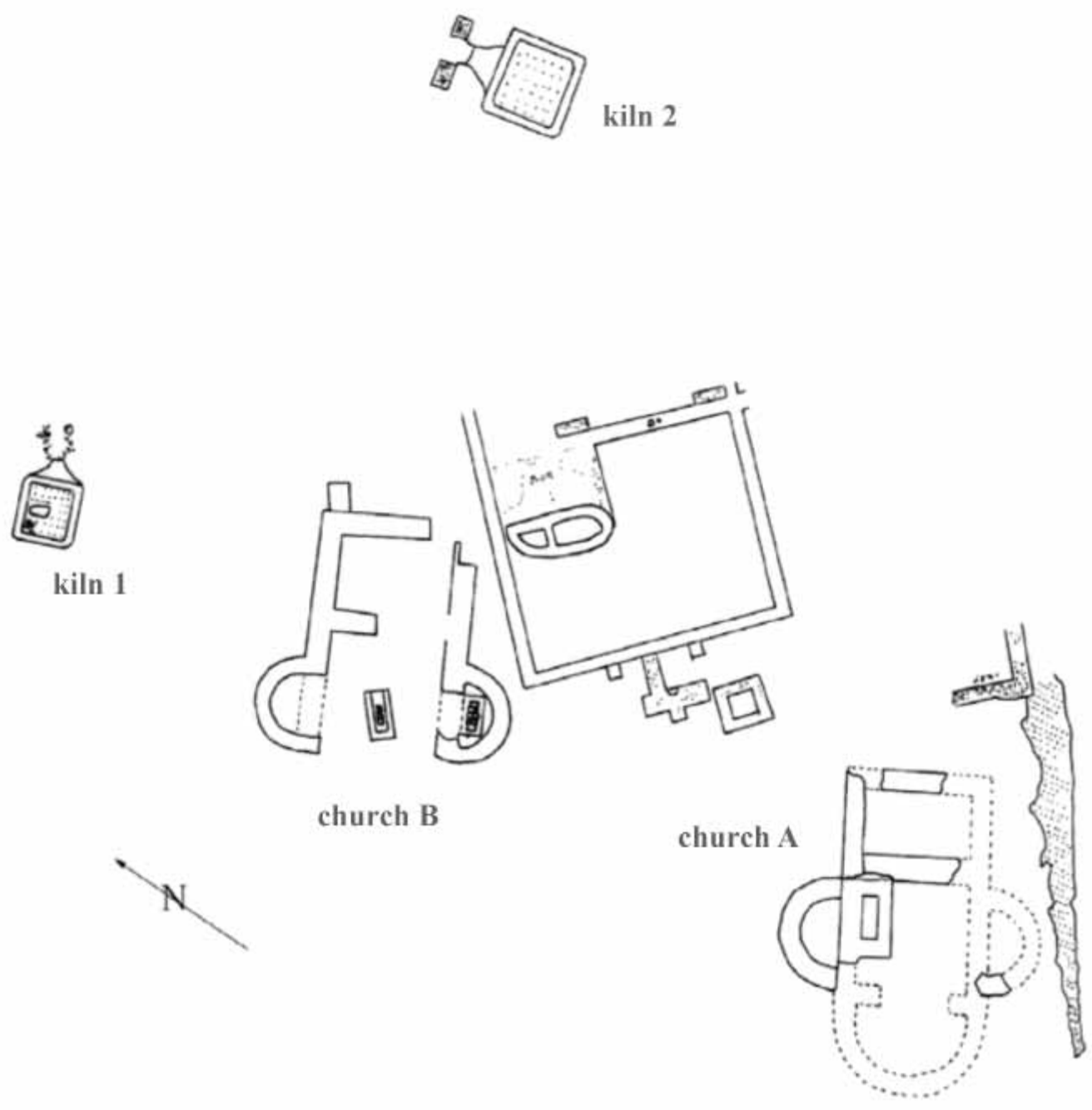

Figure 2. Situation plan of the site Pećine, southeast from the site Livade kod ćuprije

pedestal. One third of the semicircular wall is preserved, which is the eastern part of the wall. Pilasters were built at the place where apse joined the walls 1 and 2 . The dimensions of pilasters were 70 x $60 \mathrm{~cm}$. The highest preserved part of the wall is $55 \mathrm{~cm}$. Traces of charcoal, burned soil and debris were found on the surface in the northeastern corner of the Room 1 . The dimensions of the surface were $2,80 \times 1,65 \mathrm{~m}$.

Rooms 2, 3 and 4 are located in the southeastern corner of the object. Rooms 2 and 3 which have the same lengths were located east of Room 1. The dimensions of Room 2 are 4,35 x 2,0 m. The dimensions of Room 3 are 4,35 x 2,45 m. Bones of cattle were found in northeastern cor- ner of the room. Room 4 was located east of these rooms, and its dimensions were $5,10 \times 3,80 \mathrm{~m}$. A surface with traces of charcoal, with dimensions of $60 \times 50 \mathrm{~cm}$, and thickness of $15 \mathrm{~cm}$ was found in the northwestern corner of Room 4.

In the central part of the villa there was a room that can be interpreted as a vestibule, or a lobby. Villa's vestibule is located between the southeastern wing of the object (Rooms 2, 3 and 4) and the northeastern part (Rooms 7 and 8). The room was closed from south, west and north with the walls of other rooms, while the eastern side was open. A ceramic kiln from an older period was found in the villa's vestibule, beneath wall 4. The kiln was located $70 \mathrm{~cm}$ below the lower 


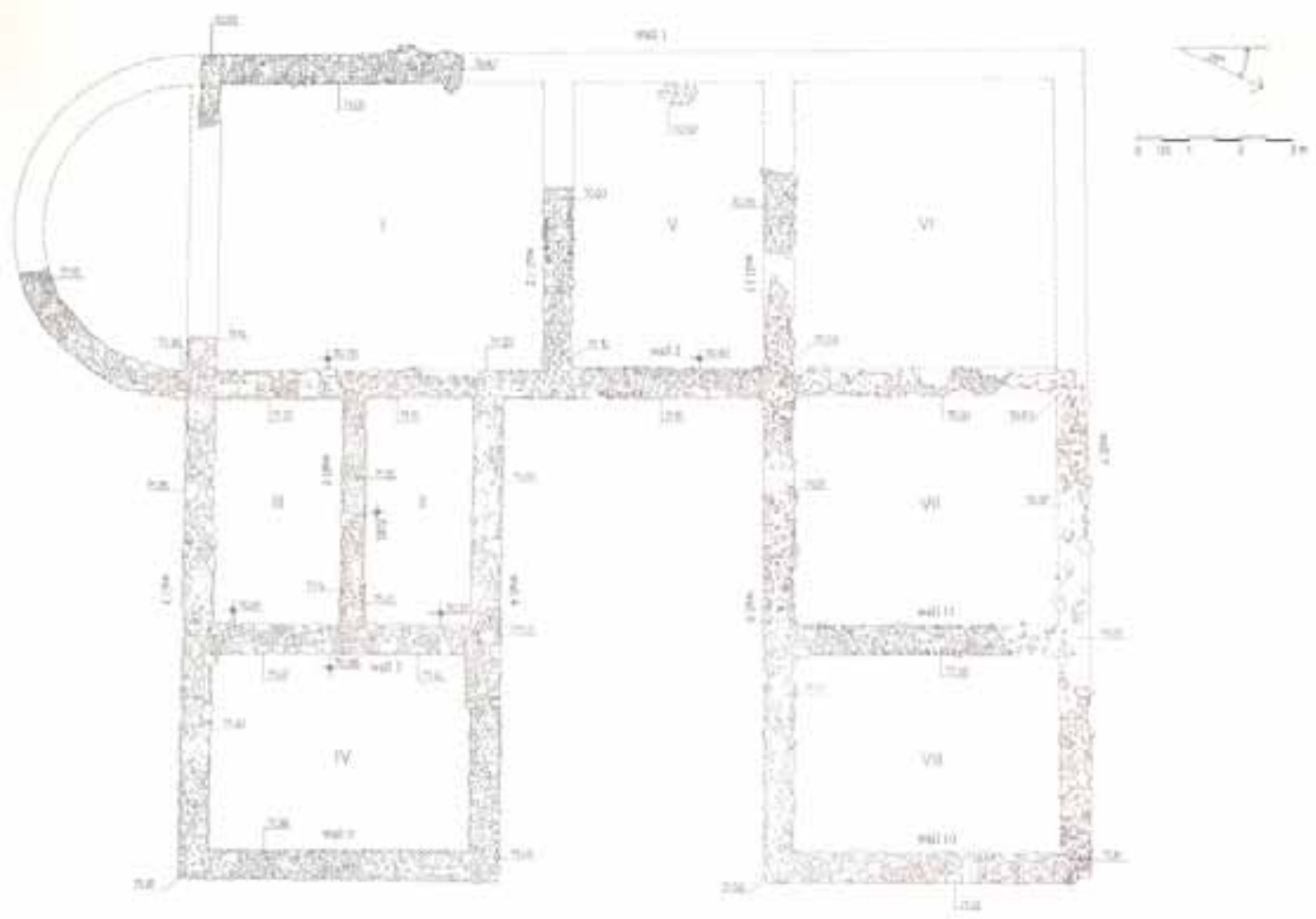

Figure 3. Plan of the villa rustica at the site Livade kod ćuprije

grade level of the wall. The height of the kiln is preserved at $0,97 \mathrm{~m}$, with a cylindrical burner (diameter of $1,40 \mathrm{~m}$ ) and it's dated to the period of the $2^{\text {nd }}$ and $3^{\text {rd }}$ century A.D. (Fig. 5).

Room 5 is located north of Room 1, and west of the vestibule. The north, west and south walls of the room were partially destroyed during mechanization. According to reconstruction, the dimensions of Room 5 are 5,75 x 3,70 m.

Rooms 6, 7 and 8 were in the northern wing of the object. Room 6 is located in the northwestern corner of the construction. Walls 1 and 7 which closed the room from western and northern side, were completely destroyed by mechanization works. The dimensions of Room 6 are 5,75 x 5,05 m. Room 7 is located east of Room 6. Like as previously mentioned rooms, the walls of this one were also partially destroyed by mechanization works. One row of brick fragments in foundation zone is the only preserved part of western and northern walls. The dimensions of Room 7 are
5,05 x 4,35 m. Room 8 in the northeastern corner of the villa was located east of the Room 7. The dimensions of Room 8 are 5,05 x 3,85 m.

\section{The Finds}

Many finds made of iron, bronze, lead, stone and bone were found in the villa's layer. Most notable iron artifact is an iron arrow shaped tool with a spoon-shaped handle (T.I/1). It was found in the vestibule's layer, near wall 8 . This artifact can be interpreted as a drill, a tool used for drilling wood by carpenters and cart wrights. ${ }^{26}$ A small fragmented and corroded iron axe with a breech was found in Room 4 (T.I/2). This axe belongs to a certain type of axe hammers, and the blade is evenly wide from the breech to the point. ${ }^{27}$ These types of axes represent combined

26 Поповић 1988, 118, 119, Т.XX. 3-6.

27 Поповић 1988, 69. 


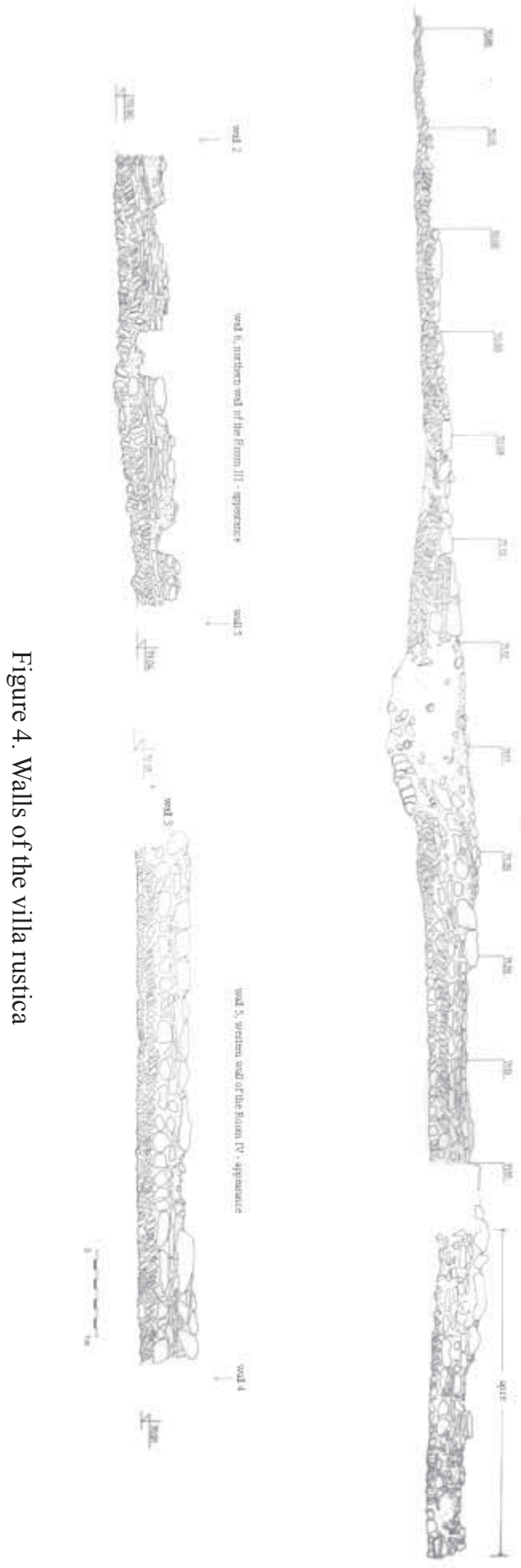

weapons. They could also been used as hammers, because they have a prism-like end, but they were primarily used by woodcutters. Axes of this type were widespread throughout the Antique period. An iron ring was also found in the southern part of this room (T.I/3).

The most common are bronze artifacts, and count the findings of coins, a fibula, needles, a rings and an application. Nine bronze coins were found in the rooms and vestibule. According to available documentation, 6 coins were dated in the middle and the second half of the $4^{\text {th }}$ century A.D. ${ }^{28}$ They are the coins of Julian, Valens, Valentinian I, Valentinian II and Theodosius I. Only one fibula has been discovered in the object, in the Room 8. It is a bronze crossbow fibula, which doesn't have a part of the bow, the head and the pin (T.I/4). The bow has trapezoidal cross-section, longitudinally decorated with carvings. It has a long body with a circular decoration. Crossbow fibulae were testified with 79 samples on the territory of Viminacium, and all are from the $4^{\text {th }}$ century. ${ }^{29}$ This type of crossbow fibula has no direct analogy, but it is the most similar to the fibulae from Timacum Minus and Romuliana, type 34d, subvariant 2 - according to the typology made by S. Petković, and which she dated from 364 to 380 A.D. ${ }^{30}$ A bronze sewing needle with a rectangular perforation was found in the same room (T.I/5). The needle was broken and slightly deformed. Such needles are commonly found (Belgrade, Ritopek, Ušce near Obrenovac, Zemun) and dated, based on the context, to the $2^{\text {nd }}$ and $3^{\text {rd }}$ century A.D. ${ }^{31}$ A deformed bronze needle was found in the villa's vestibule. A larger bronze ring of a semicircular cross-section was found in Room 3, while a bronze application with a safety pin was found in Room 4 (T.I/6).

A miniature lead mirror with a handle was found in the northwestern corner of Room 2

28 According to the data from excavation field diary. 29 Redžić 2007, 65-66. 30 Petković 2010, 264-265, S1. 93, S1 94. 31 Крунић 1997, 215-216, бр. 330-335. 


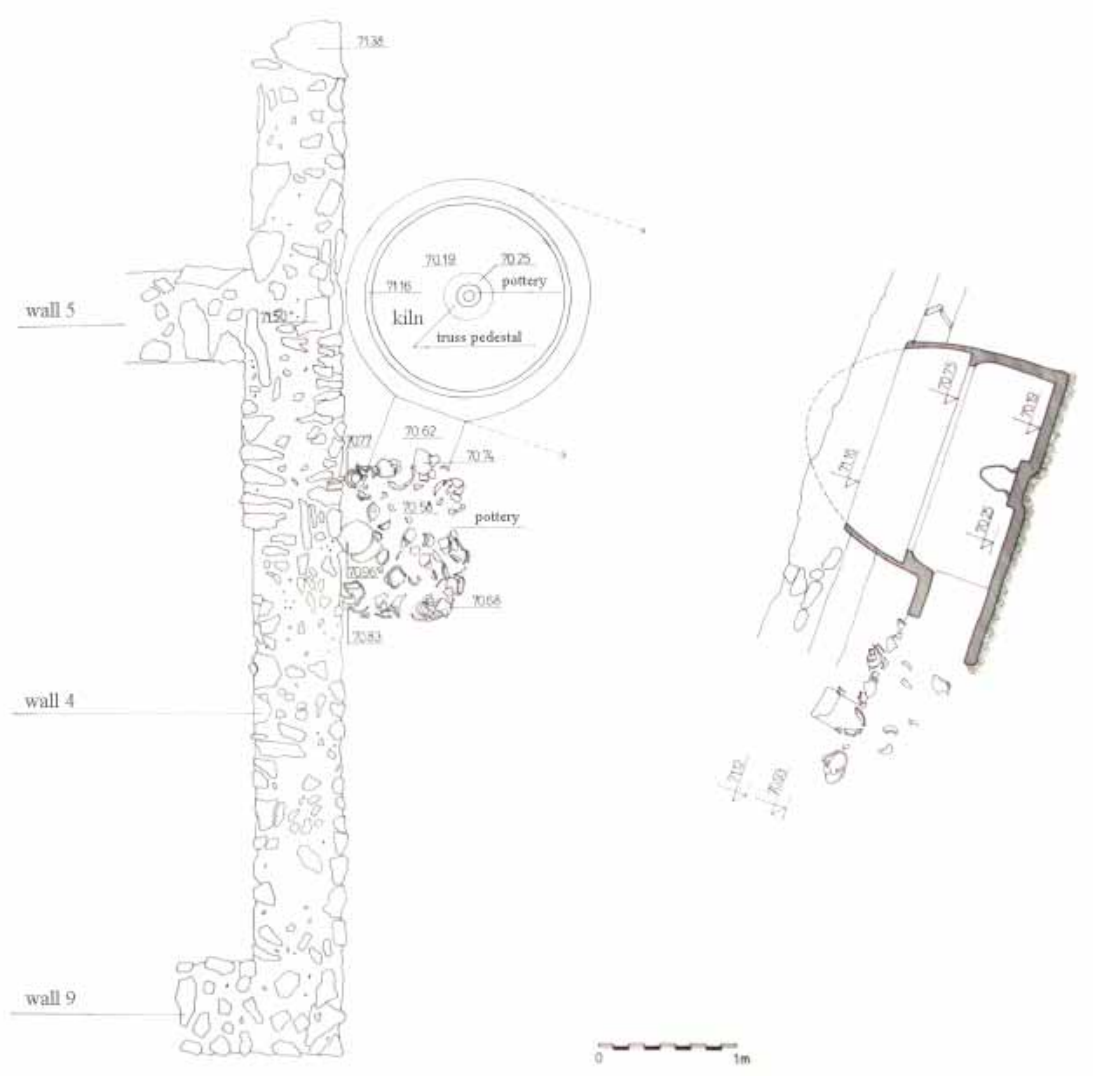

Figure 5. Wall 5 and a pottery kiln from the older period
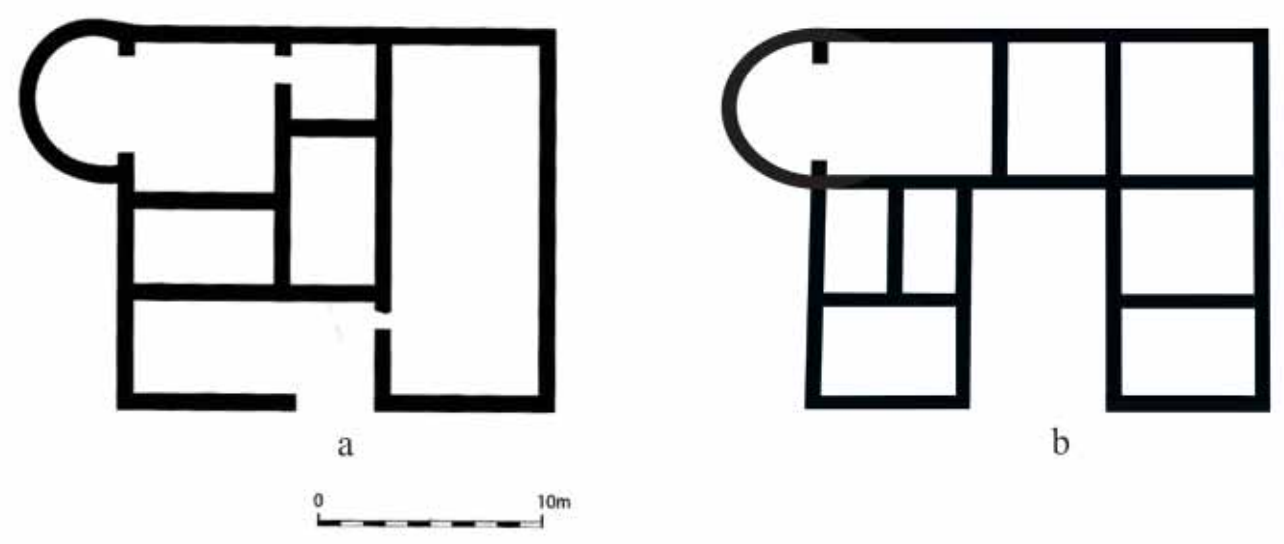

Figure 6. a) Krivelj near Bor; b) Livade kod ćuprije - plans of the villas

(T.I/7). It is ornamented on the back side, and the front side is damaged. Anterior part of the circular frame of the mirror is divided in two fields. In one of the fields, appears a motive of connected ellipse ornaments, which form a chain around the mirror frame or on the outer line. The inner field is divided in four sections by vertical lines, which form a herringbone motif ( $\mathrm{V}$ motive). These lines form a schematic wreath. The mirror is type IV/2 according to B. Milovanović. Three mirrors of 
this type were found in Danube region, two in Viminacium - one at the site Cair, and one at the site Pirivoj. B. Milovanović dated this type in the first half of the $4^{\text {th }}$ century A.D. ${ }^{32}$

Concerning the artifacts made of stone, we should mentioned one whetstone, found in Room 8 (T.II/1). A piece of marble wall paneling was found in Room 3. One of its edges was polished, and it represents the remains of the wall's marble decoration (T.II/2). Another piece of marble board was found bricked into wall 2. That is a reused marble tombstone (T.II/3). The data refer to the age of the deceased are readable. According the letters and hederas which were properly carved, the tombstone was dated to the period of the $2^{\text {nd }}$ century, or the beginning of the $3^{\text {rd }}$ century.

Processing is noticed on deer antler fragment which was cut. The antler was unfinished piece (T.II/4). These antler tines can often be found on Antique sites in Upper Moesia. ${ }^{33}$ These tines were further used in bone carving workshops for making plates, cuts, spikes, pipes, that were later carved into other desired items.

Fragments of pottery found in villa's rooms belong to the repertoire of the $4^{\text {th }}$ century. A green enameled lamp, characteristic for the $4^{\text {th }}$ century was found in trench 1 near the villa.

\section{DISCUSSION}

Based on the finds discovered in villa's rooms, the object can be dated to the second half of the $4^{\text {th }}$ century. Most of the investigated villas in Viminacium were also dated to the $4^{\text {th }}$ century (Map 2). Villas at the sites Na Kamenju, ${ }^{34}$ Stig $^{35}$ and Burdelj ${ }^{36}$ are dated to the middle of the $4^{\text {th }}$ century. Second phase of Structure 1 at the site Rudine is dated to the end of the $3^{\text {rd }}$ and begin-

32 Milovanović 2009, 127-128.

33 Petković 1995, 55-56.

34 Golubović, Korać 2008, 35.

35 Redžić, Raičković, Miletić 2006, 49.

36 Зотовић 1986, 56, nap. 28. ning of the $4^{\text {th }}$ century, while Structures 2 and 3 are dated to the end of the $4^{\text {th }}$ and beginning of $5^{\text {th }}$ century. ${ }^{37}$

Similar situation is noticed with explored villas on the territory of Serbia. Most of them are dated to the $4^{\text {th }}$ century, a period when they are numerous on the territory of Moesia Prima,${ }^{38}$ Dacia Mediterranea ${ }^{39}$ and Pannonia Secunda..$^{40}$

Villa phenomenon is related to the end of the $1^{\text {st }}$ and the beginning of the $2^{\text {nd }}$ century A.D. in the most provinces of the Empire. However, the increased number of villas in all area is typical for the $4^{\text {th }}$ century, when colonatus was the dominant system. ${ }^{41}$ During this period, old villas are renovated and new ones are built, and there is a development of large land ownership. ${ }^{42}$ Villas are often fortified, because there was a risk of barbaric invasions. The $4^{\text {th }}$ century is a period of economical stability, and a more basic, staider way of manufacturing.

Roman villa at the site Livade kod ćuprije is a type of villa with a rectangular basis and a central corridor. ${ }^{43}$ Villas with a central corridor are typical for the territory of Pannonia. ${ }^{44}$ Villas with similar basis and dimensions were also

37 Поповић, Иванишевић 1988, 170.

38 Vasić 1995, 335, Map 1; Ilić 2012, 101-113.

39 On the site Mediana south of the representative peristyle villa, the remains of smaller villa rustica were found, that are dated to the $4^{\text {th }}$ century, see: Дрча 2006, 24-28; In the area of Remesiana, a larger peristyle villa was found in Bela Palanka, while the remains of another villa are in the village Dol, see: Milošević 2004, 128; Late Antique period villas were found during the construction of highway E-75 in 2003. For the villa in Mala Kopašnica, see: Фидановски, Цвјетићанин 2005, 67-83, T.VI-T.XIV. For the villa in Kržince near Vladičin Han see: Ружић, Брмболић, Манојловић-Николић 2005, 203-225.

40 Late Antique period villas were found on the sites Livade near Sremska Mitrovica, Šašinci, Dumbovo near Beočin and Hrtkovci. For villas on the territory of Srem see: Брукнер 1995, 137-174; Даутова Рушевљан 2008, 287-312.

41 Percival 1981, 46.

42 Percival 1981, 46-49, 166-182; For Pannonia see: Biró 1974, 52.

43 For villa types see: Smith 1997; Biró 1974, 40; Vasić 1970, 54-62.

44 Tomas 1964, 162, Abb.177. 
found in Serbia. Such villas are Poskurice near Kragujevac, ${ }^{45}$ Višesava near Bajina Bašta ${ }^{46}$ and Krivelj near Bor, ${ }^{47}$ and the last one is the most similar to the villa at the site Livade kod ćuprije (Fig. 6).

Finds inside the villa, besides the items for daily use and clothing, indicate craftsmanship and agricultural labor. Axes, drill and the semi fabricate of a antler suggest an intense woodwork and bone tools processing, while the whetstone is evidence of agricultural activity. The marble decoration in Room 3 indicates that the villa was also used for the accommodation of the owner, not just for economical purpose. However, since remains of heating, floors or mural decorations were not found, it can be assumed that it was not a luxurious object. Room 1 with an apse could have been a receiving room, or dining-room (triclinium). Villas dated to $4^{\text {th }}$ century often have an apse, served as so called Late Antique representative aula which was modeled after the central aula of imperial palaces.

It is difficult to make any reliable conclusion when it comes to the size of the estate and the role of this villa mostly because of its level of investigation. Did this villa have auxiliary objects on the property, or it was itself an auxiliary object of a larger household? The villa's owners could have been of different social status. During the Roman period there were imperial and senatorial properties, properties of roman or local aristocracy, and the owners of the villa could have been veterans, or small landowners. ${ }^{48}$ Veterans were given property after their service, and they were owners of smaller and simpler villas. M. Vasić linked the frequent appearance of villas on the territory of Moesia Prima with the period of Valentinian I and his border army, i.e. limitanei. After the act of Emperor from the year 364 there

45 Петровић 1966, 254, сл. 5. 46 Бућић, Петровић 1986, 33, сл. 11. 47 Јевтић 1996. сл.1. 48 Begović, Schrunk 2003, 99. was a greater appearance of properties. During that period emperors were granting to the veterans considerable estates. Private soldiers were allotted pair of oxen and 50 modes of wheat, what was sufficient to plant about 10 to 12 yokes of land. ${ }^{49}$ Those of higher rank were allotted two pairs of oxen and twice the amount of wheat. Vasić believes that the colonate was established in the Iliricum rather late, not before the prefecture of Anatolius in 371, so most lands were cultivated by independent farmers, who existed until the end of the $4^{\text {th }}$ century. These properties had a significant role in the province's economy, because the owners supplied the urban settlements with agricultural products and paid taxes regularly. The villa at the site Livade kod ćuprije, according to the size and character of object was just a small property of a veteran or an independent farmer. The life period of villa confirms this hypothesis.

\section{CONCLUSION}

Considering the territory of Viminacium, the discovery of villa rustica on the site Livade kod ćuprije increases the knowledge of this area of interest in many ways, and contributes to the research of villas on the territory of Moesia. As it can be seen the duration of the villa is dated in the middle and second half of the $4^{\text {th }}$ century, which coincides with the period of greatest prevalence of villas on our territory, but also with the situation in other provinces of the Empire. The villa is made of stone, brick and mortar, techniques commonly applied in building of others objects of the same period. Typologically, the villa has a rectangular basis with a central corridor or a vestibule. This type of villa was common on the territory of Pannonia in the $4^{\text {th }}$ century, but similar villas can also be found on the territory of Moesia.

The villa at the site Livade kod ćuprije is not a residential villa of a big estate but rather of

49 Vasić 1995, 329. 
medium or small farm. In addition to the residential character of the villa, its rooms were places of economic activities which were characteristic for daily life in a rural household. The remains of villa on the territory south of the town, which was used from the $1^{\text {st }}$ to the $3^{\text {rd }}$ century as a necropolis, indicate that rural households were formed after the initial function of southern necropolis was finished. The previously mentioned remains of a rural object at the site Burdelj ${ }^{50}$ located about $500 \mathrm{~m}$ southeast of the site Livade kod ćuprije, confirm this hypothesis. The owner of the property could have been a veteran or independent farmer who sold his services and products in the town.

translated by the author

\section{BIBLIOGRAPHY}

\section{Adam 2005}

J. P. Adam, Roman Building Materials and Techniques, London and New York 2005.

\section{Begović, Schrunk, 2003}

V. Begović, I. Schrunk, Rimske vile Istre i Dalmacije, II dio: tipologija vila, Pril. Inst. Arheol. Zagrebu, 20/2003, Zagreb, 95-112.

\section{Biró 1974}

M. Biró, Roman villas in Pannonia, Acta Archaeologica Academiae Scientiarum Hungaricae 26, Budapest 1974, 23-57.

\section{Брукнер 1995}

О. Брукнер, Римска насеља и виле рустике, Археолошка истраживања дуж аутопута кроз Срем, Нови Сад 1995, 137-174.

\section{Бућић 1986}

J. Бућић, П. Петровић, Римска вила у Вишесави код Бајине Баште, Ужички зборник 15, Титово Ужице 1986, 23-42.

\section{Даутова Рушевљан 2008}

В. Даутова Рушевљан, Систематско-заштитна ископавања на локалитету Врањ у Хртковцима 2005-2006. године, Гласник Српског археолошког друштва 24, Београд 2008, 287-312.

\section{Дрча 2006}

С. Дрча, Медијана, Ниш 2006.

\section{Милошевић 2004}

Г. Милошевић, Ремесијана - слика једног античког града, Пешчаник II, Ниш 2004, 121 133.

\section{Фидановски, Цвјетићанин 2005}

С. Фидановски, Т. Цвјетићанин, Римска вила и некропола на локалитету Каменитица Моравиште у Малој Копашници код Грделице, Археолошка истраживања E-75, свеска 1, Београд 2005, 49-121.

\section{Golubović, Korać 2008}

S. Golubović, M. Korać, The Recent Discovery of a Temple Complex at Viminacium, Bollettino di archeologia on line, Roma 2008, 33-36.

\section{Ђокић, Јацановић 1992}

Д. Ђокић, Д. Јацановић, Топографска грађа Стига, VIMINACIUM 7, Пожаревац 1992, 61110.

\section{Ilić 2012}

O. Ilić, Poljoprivredna proizvodnja u rimskim provincijama na tlu Srbije, od I do prve polovine $V$ veka, Filozofski fakultet, doktorska disertacija, Beograd 2012.

\section{Јевтић 1966}

М. Јевтић, Керамика старијег и млађег гвозденог доба са налазишта Старо Гробље у Кривељу код Бора, Зборник HM XVI/1, Београд 1996, 129-142.

50 Зотовић 1980, 97; Зотовић 1986, 51. 


\section{Jovičić 2011}

M. Jovičić, Vile rustike na teritoriji Viminacijuma, Filozofski fakultet, master rad, Beograd 2011.

\section{Крунић 1997}

С. Крунић, Античка бронза Сингидунума, Београд 1997.

\section{Leleković, Rendić-Miočević 2012}

T. Leleković, A. Rendić-Miočević, Rural Settlements, The Archaeology of Roman Southern Pannonia (ed. B. Migotti), BAR International Series - Oxford 2012.

\section{Mikić, Stojanović, Mrđić 2006}

M. Mikić, V. Stojanović, N. Mrđić, Primena gradiometra za potrebe zaštitnih arheoloških istraživanja na Viminacijumu - lokalitet Rit, Arheologija i prirodne nauke 2, Beograd 2006, 21-26.

\section{Milovanović 2009}

B. Milovanović, Rimsko olovo u Srbiji-eksploatacija, proizvodnja $i$ upotreba, Filozofski fakultet, doktorska disertacija, Beograd 2009.

\section{Mirković 1986}

M. Mirković, Inscriptions de la Mesie Superieur, vol. II . Viminacium et Margum, Beograd 1986.

\section{Petković 1995}

S. Petković, Rimski predmeti od kosti i roga sa teritorije Gornje Mezije, Beograd 1995.

\section{Petković 2010}

S. Petković, Rimske fibule u Srbiji, Beograd 2010.

\section{Петровић 1966}

Д. Петровић, Остаци римске грађевине у Поскурицама, Старинар XV-XVI, Београд 1966, 253-256.

\section{Percival 1981}

J. Percival, The Roman Villa, An Historical Intro- duction, London 1981.

Поповић 1968

В. Поповић, Уводу топографију Виминацијума, Старинар XVIII/1967, Beograd 1968, 29-49.

\section{Поповић 1988}

И. Поповић, Античко оруђе од гвожђа у Србији, Београд 1988.

\section{Поповић, Иванишевић 1988}

М. Поповић, В. Иванишевић, Град Браничево у средњем веку, Старинар XXXIX, Београд 1988, 125-179.

\section{Raičković, Redžić 2006}

S. Redžić, A. Raičković, Keramičke i opekarske peći Viminacijuma - lokacije "Pećine" i "Livade kod ćuprije", Arheologija i prirodne nauke 1, Beograd 2006, 81-105.

\section{Raičković 2007}

A. Raičković, Keramičke posude Zanatskog centra iz Viminacijuma, Beograd 2007.

\section{Redžić, Raičković, Miletić 2006}

S. Redžić, A. Raičković, V. Miletić, Arheološka istraživanja lokaliteta Stig na osnovu georadarskih ispitivanja, Arheologija i prirodne nauke 1, Beograd 2006, 47-56.

\section{Redžić 2007}

S. Redžić, Nalazi rimskih fibula na nekropolama Viminacijuma, Beograd 2007.

\section{Ружић, Брмболић, Манојловић-Николић 2005 \\ М. Ружић, М. Брмболић, В. Манојловић-Нико- лић, Кржинце - Свети Тројица (касноантичка вила), Археолошка истраживања Е-75, свеска 1, Београд 2005, 203-225.}




\section{Smith 1997}

J. T. Smith, Roman Villas, a study in social structure, London 1997.

\section{Спасић - Ђурић 2002}

Д. Спасић - Ђурић, Виминачијум главни град римске провиниије Горње Мезије, Пожаревац 2002.

\section{Thomas 1964}

E. Thomas, Römische Villen in Pannonien, Budapest 1964.

\section{Vasić 1970}

M. Vasić, Römische Villen vom Typus der Villa rustica auf jugoslawischen Boden, Archeologia Iugoslavica XI, Beograd 1970, 45-81.

\section{Vasić 1995}

M. Vasić, Moesia Prima and Dacia Ripensis in the time of Valentinian and Valens (364-378 A.D.), The Age of Tetrarchs (ed. D.Srejović), Beograd 1995, 324-335.

\section{Зотовић 1980}

Љ. Зотовић, Некропола из времена сеобе народа са уже градске територије Виминацијума, Старинар XXXI, Београд 1980, 95-128.

\section{Зотовић 1986}

Љ. Зотовић, Јужне некрополе Виминацијума и погребни обреди, Viminacium I, Пожаревац 1986, 41-60.

\section{Зотовић, Јордовић 1990}

Љ. Зотовић, Ч. Јордовић, Viminacium 1, Некропола Више гробаља, Београд 1990.

\section{KASNOANTIČKA VILA NA LOKALITETU ,LIVADE KOD ĆUPRIJE" - PRILOG PROUČAVANJU VILA RUSTIKA NA TERITORIJI VIMINACIJUMA}

Tokom dugogodišnjeg istraživanja Viminacijuma, iako veoma značajne za istraživanje privrede jednog grada, vile rustike nisu dobile dovoljno naučne pažnje. Vile rustike predstavljaju model zemljoposeda i poljoprivredne proizvodnje karakterističan za period kasne Republike i za ceo period Carstva, odnosno agrikulturno gazdinstvo sa prostorijama za smeštaj vlasnika (pars urbana) koje su odvojene od proizvodnog dela vile (pars rustice) i u kome su odaje za proizvodnju, skladištenje, štale, mlinovi, radionice, kao i objekti za smeštaj robova i osoblja.

Viminacijum je najveće gradsko naselje u provinciji Gornjoj Meziji, nastalo u I veku na desnoj obali Mlave u blizini njenog ušća u Dunav. Nakon 86. godine Viminacijum je postao glavni grad provincije Gornje Mezije (Moesia Superior), a nakon Dioklecijanove reforme provincije Prve Mezije (Moesia Prima) sa stalnom vojnom posadom legije VII Claudia. Antički grad nije bio ograničen samo na naselje već je obuhvatao i širi prostor - ager ili territorium, koji se prostirao na teritoriju Stiga. Tokom dugogodišnjeg istraživanja Viminacijuma na toj teritoriji istraženi su ostaci više vila rustika, i to na lokalitetima Burdelj, Livade kod ćuprije, Na Kamenju, Nad Klepečkom, Rit, Rudine i Stig.

U radu je predstavljena kasnoantička villa rustica pronađena na lokalitetu Livade kod ćuprije koji se nalazi $650 \mathrm{~m}$ južno od Viminacijuma, u neposrednoj blizini lokaliteta Pećine. Vila je istražena 1983. godine prilikom zaštitnih istraživanja u krugu termoelektrane Kostolac B, međutim rezultati tih istraživanja do danas su ostali nepoznati naučnoj zajednici. Objekat kao i kasnoantički sloj na prostoru oko njega naslojavaju se na sloj iz starijeg perioda, tačnije ispod objekta istraženi su ostaci lončarske peći iz II-III veka. 
Istraženi objekat je pravougaone osnove, sastoji od 8 prostorija i jednog većeg predvorja $\mathrm{u}$ centralnom delu. Prostorija I u jugozapadnom delu vile imala je proširenje u vidu polukružne apside i ova prostorija bi mogla biti prostorija za prijem ili za obroke (triclinium). Dimenzije istražene vile iznose 21 x 16,30 m. Temeljna stopa objekta zidana je u suhozidu od lomljenih komada opeke i lomljenog škriljca, visine do $20 \mathrm{~cm}$. Nadzemni deo zida zidan je od pravilno ređanih većih komada kamena škriljca i opeke koji su vezani krečnim malterom, a ostaci zidova očuvani su maksimalno do $60 \mathrm{~cm}$.

U kulturnom sloju koji odgovara periodu života vile otkriveno je više pokretnih nalaza: svrdlo, gvozdena sekira, gvozdena i bronzana alka, devet bronzanih novčića, bronzana krstasta fibula, bronzana šivaća igla, olovno ogledalo, kameni brus, fragment mermerne oplate zida, sekundarno upotrebljeni deo nadgrobnog spomenika uzidan u zid objekta, i polufabrikat od roga. Fragmenti keramike pronađeni $\mathrm{u}$ prostorijama vile pripadaju repertoaru IV veka. Pokretni nalazi pored predmeta svakodnevne upotrebe i delova odeće predstavljaju i predmete korišćene za zanatske delatnosti i poljoprivredne radove.

$\mathrm{Na}$ osnovu pomenutih nalaza pronađenih u prostorijama vile, objekat se može datovati u period sredine i druge polovine IV veka. Upravo periodu IV veka pripada i najveći broj istraženih vila na Viminacijumu, na lokalitetima Burdelj, $\mathrm{Na}$ Kamenju, Stig i Rudine. Vila na lokalitetu Livade kod ćuprije tipološki gledano pripada tipu vila pravougaone osnove sa centralnim koridorom karakterističnim za prostor Panonije, koji se sreće i na našoj teritoriji. Direktne analogije nalazimo na lokalitetu Krivelj kod Bora.

Vila Livade kod ćuprije, prema veličini i karakteru objekta, može predstavljati manji posed nekog veterana ili slobodnog seljaka. Za period vladavine Valentinijana karakteristično je da je Imperator veteranima dodeljivao zemlju, a upravo se i vila sa lokaliteta Livade kod ćuprije vezuje za ovaj period.
Ostaci vile rustike na teritoriji južno od grada, koja je tokom perioda od I do kraja III veka korišćena kao nekropola, govore da su nakon prestanka prvobitne funkcije, na teritoriji južnih nekropola formirana gazdinstva ruralnog karaktera. Ostaci ruralnog objekta na lokalitetu Burdelj nalaze se na udaljenosti od oko 500 m jugoistočno od lokaliteta Livade kod ćuprije što takođe ide u prilog ovoj tvrdnji. 
T.I
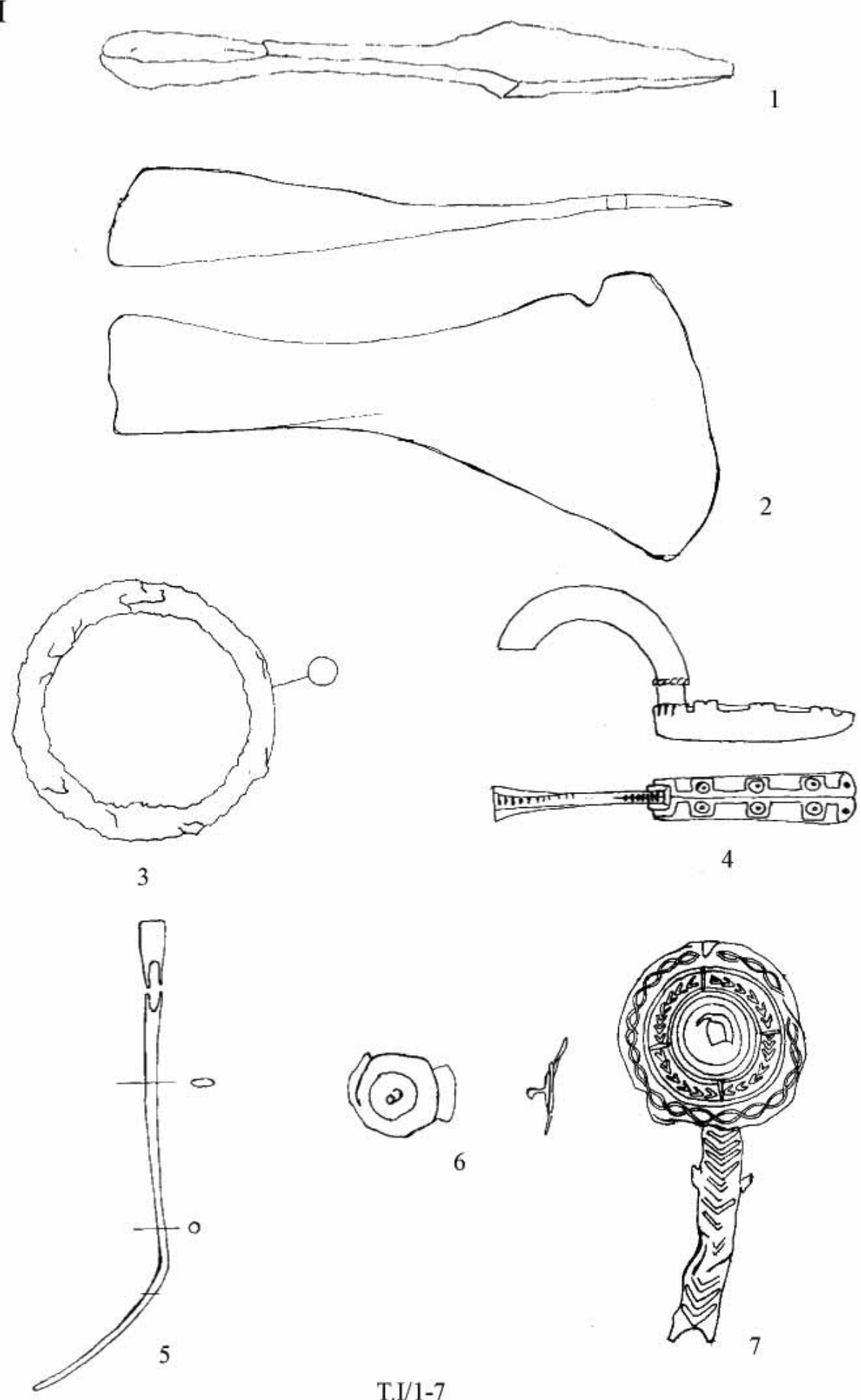

(2)

6
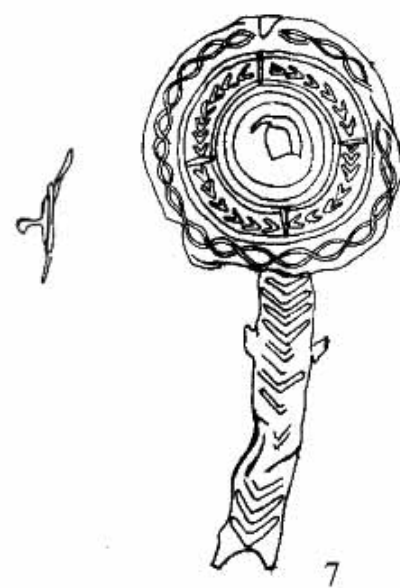

T.I/1-7 
T.II
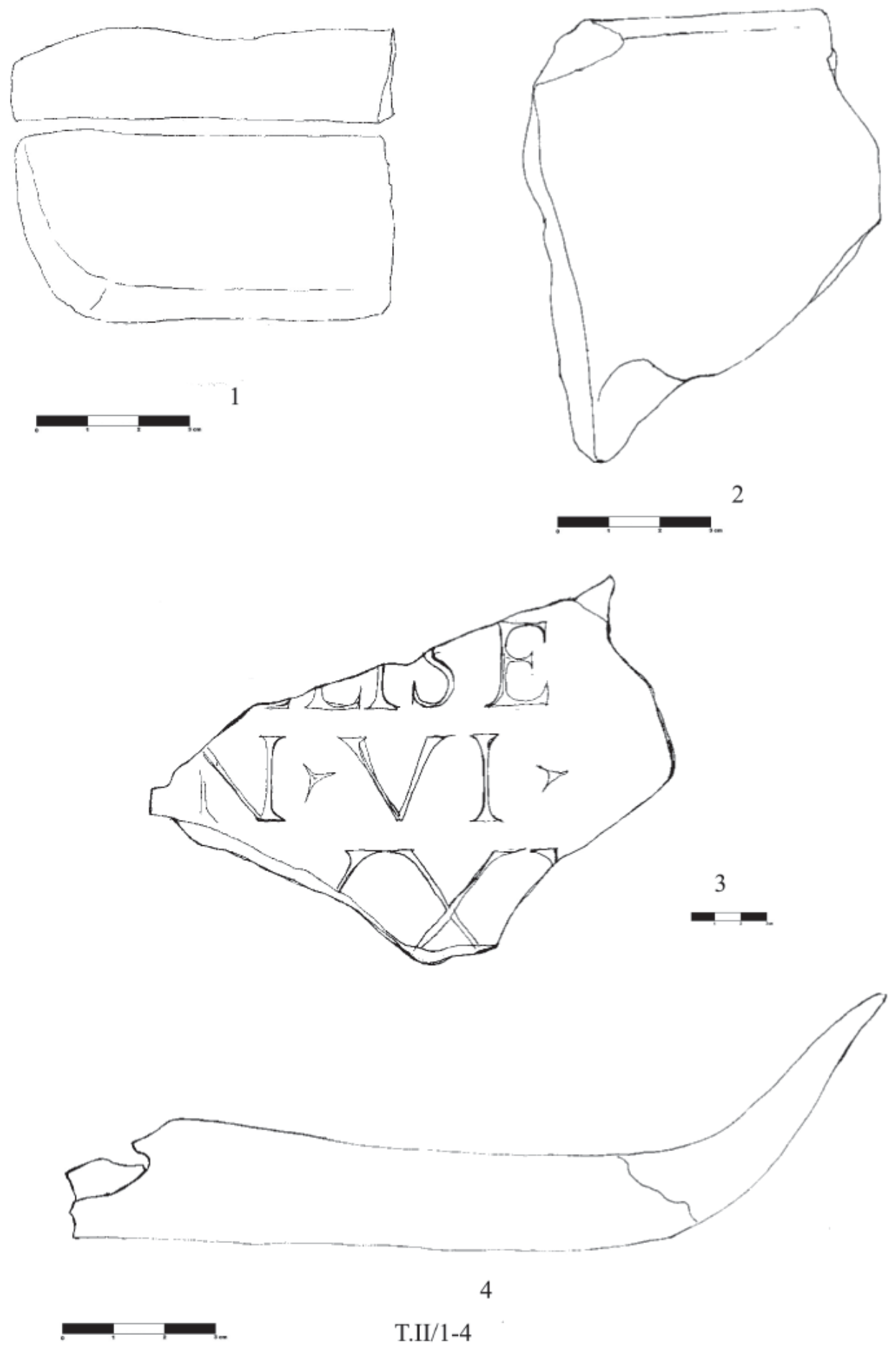